\title{
MENINGKATKAN KEMATANGAN KARIR SISWA SMP MELALUI PELATIHAN PERENCANAAN KARIR
}

\author{
Maulidia Ghassani, Ni'matuzahroh', Zainul Anwar
}

Fakultas Psikologi, Universitas Muhammadiyah Malang

\begin{tabular}{l} 
Keywords/Kata kunci \\
\hline career maturity, career \\
planning, CASVE cycle, \\
training.
\end{tabular}

CASVE cycle, kematangan karir, pelatihan, perencanaan karir.

\begin{abstract}
ABSTRAK:
The research objective was to increase the career maturity of junior high school students through career planning training based on five stages of decision making CASVE Cycle (Communicating, Analyzing, Synthesis, Valuing, Exception). The research method was a quasi-experimental study with a one-group pretest-post test group design. The research subjects were 10 students who were taken by purposive sampling. The research instrument used a career maturity scale and data analysis used the Wilcoxon statistical test. The results showed that career planning training increased the career maturity of junior high school students.

Tujuan penelitian untuk meningkatkan kematangan karir siswa sekolah menengah pertama melalui pelatihan perencanaan karir yang didasarkan pada lima tahap pengambilan keputusan CASVE Cycle (Communicating, Analysing, Synthesis, Valuing, Excecution). Metode penelitian ini menggunakan kuasi-eksperimen dengan desain one-group pretest-paska tes group. Subjek penelitian ini berjumlah 10 siswa yang diambil secara purposive sampling. Instrumen penelitian ini menggunakan skala kematangan karir dengan analisis data menggunakan uji Wilcoxon. Hasil penelitian ini menunjukkan bahwa pelatihan perencanaan karir mampu meningkatkan kematangan karir siswa sekolah menengah pertama.
\end{abstract}

\footnotetext{
${ }^{1}$ Korespondensi mengenai artikel ini dapat dilakukan melalui zahroh@umm.ac.id/nimatuzahroh7@gmail.com.
} 
Masa remaja adalah masa dimana kemampuan kognitif remaja telah berkembang untuk dapat berpikir kritis, seperti melakukan evaluasi, pengambilan keputusan, komitmen, dan mulai menetapkan posisi mereka dalam realita hidupnya (Santrock, 2011). Erikson menekankan bahwa pengembangkan kesadaran terhadap pekerjaan di masa depan merupakan hal yang harus dinavigasi oleh remaja pada tahap pengembangan identitas ini (Russ, 2016). Hal yang sama dikemukakan Havighurst bahwa memilih dan mempersiapkan sebuah pekerjaan menjadi salah satu dari sembilan tugas perkembangan yang harus diselesaikan sebelum akhir remaja (Dhayanandhan, Bohr, \& Connolly, 2015; Russ, 2016). Keberhasilan tercapainya tugas-tugas tersebut dipengaruhi oleh faktor kematangan fisik, tuntutan masyarakat, dan motivasi dari dalam diri sendiri (Marliyah et al., 2004).

Mengacu pada teori perkembangan karir, masa remaja termasuk ke dalam exploratory stage, remaja mencoba menentukan pilihan karir apa yang harus diambil dan bagaimana melangkah menuju pilihan tersebut secara akademis (Tressler, 2015). Perkembangan karir adalah proses bertahap selama rentang masa kehidupan, pada setiap tahapnya memiliki tugas pokok tersendiri sesuai dengan kapasitas perkembangannya (Zunker, 2006). Penyelesaian tugas yang tepat di setiap tahapan adalah indikator dari kematangan karir (Zunker, 2006). Kematangan karir merujuk pada kondisi kesiapan seseorang untuk memilih dan mengelola karir di samping mengelola tugas sehari-hari yang diindikasikan dengan kemampuan individu mengenali masalah yang dihadapi, serta seberapa jauh dapat mengatasi tugas perkembangan tersebut (Talib, et.al., 2015). Adapun aspek-aspek dalam kematangan karir menurut Super, yaitu career planning, career exploration, information, career decision making, orientation (Aquila, 2012; Fajriyah, 2015; Suryanti, Yusuf, \& Priyatama, 2004).

Tahun 2045 Indonesia diharapkan memiliki sumber daya manusia yang produktif, inovatif, kreatif, dan afektif, sehingga kurikulum 2013 dititikberatkan pada proses pendidikan yang memberi kesempatan lebih kepada peserta didik untuk mengembangkan kemampuan dan minatnya secara terarah dan optimal, sehingga generasi Indonesia memiliki minat luas dalam kehidupan, kesiapan untuk bekerja, kecerdasan yang sesuai dengan bakat dan minatnya, serta rasa tanggung jawab terhadap lingkungannya (Direktorat Jenderal Pendidikan Dasar, 2014).

Di Indonesia, setelah lulus SMP, siswa dihadapkan pada beberapa pilihan karir, seperti melanjutkan ke Sekolah Menengah Atas (SMA) ataupun Sekolah Menengah Kejuruan (SMK). Studi di SMK lebih banyak mengandung muatan praktik, sedangkan SMA lebih banyak mengandung muatan teori. Sejak berlakunya kurikulum 2013, peminatan di SMA dilakukan mulai kelas sepuluh dan mulai menjadi murid baru akan mendapatkan sembilan mata pelajaran pokok ditambah dengan empat mata pelajaran peminatannya (Afifah, 2013). Disamping itu, setelah lulus SMP, baik yang memilih SMK maupun SMA harus sudah memahami pilihan studinya sesuai dengan potensi, bakat, dan minatnya.

Fenomena yang justru berkembang di kalangan siswa SMP adalah kebanyakan siswa belum memiliki gambaran yang jelas mengenai masa depannya. Tidak jarang di antara siswa SMP memilih sekolah lanjutan tertentu karena menuruti keinginan orang tua ataupun pengaruh teman sebaya, sementara siswa sendiri kurang mengenali bakat, minat ataupun keinginan sendiri di masa mendatang (Erniwati, 2017; Lutiyem, 2016; Musfirah, 2015; Purnamasari et al., 2015). 
Hal ini diperkuat dengan temuan di lapangan pada tahun 2017 oleh peneliti pada sejumlah siswa SMP swasta di Kota Malang. Dari 30 siswa kelas sembilan yang diberi skala perencanaan karir dan diwawancarai secara mendalam, hanya enam siswa yang memiliki perencanaan karir yang jelas setelah lulus SMP. Kebanyakan siswa memilih studi lanjut yang tidak sesuai dengan bakat, minat, dan cita-cita pekerjaan yang diinginkan. Hal ini disebabkan siswa memilih sekolah hanya berdasarkan pemahaman diri yang kurang.

Kondisi tersebut akan berdampak pada saat mereka memasuki jenjang perguruan tinggi maupun saat bekerja. Siswa akan mengalami perasaan tertekan karena harus memenuhi tuntutan akademis di bidang yang sebenarnya kurang sesuai dengan dirinya sehingga berdampak pada munculnya perasaan salah memilih jurusan hingga berujung pada terjadinya drop out (Akmal et al., 2016). Hal ini juga didukung oleh Tressler (2015) yang menguraikan career indecision adalah salah satu permasalahan yang berkembang di kalangan mahasiswa saat ini yang akan berdampak pada semakin lama waktu yang dibutuhkan untuk lulus, meningkatnya pinjaman biaya sekolah, dan juga kemungkinan menurunnya kepuasan karir.

Menurut Guntur, Psikolog Pendidikan dari Integrity Development Flexibility (IDF), sebanyak 87\% mahasiswa di Indonesia mengalami salah jurusan, dan hal ini bisa berujung pada pengangguran dan stress. Menurut Zunker, (2006) keberhasilan menyelesaikan tugas-tugas perkembangan pada setiap tahapan cenderung mencapai tingkat kematangan yang lebih besar pada masa kehidupan selanjutnya. Selain itu, siswa dapat meningkatkan kematangan karir dengan belajar bagaimana cara merencanakan masa depan dan memahami kelebihan dari perencanaan tersebut.

Beberapa penelitian lain juga telah membuktikan adanya hubungan yang positif antara kesesuaian minat terhadap pekerjaan dan produktivitas kerja (Sumiwi, 2016; Telvisia \& Suyasa, 2008). Temuan ini juga diperkuat oleh pendapat Hurlock yang mengemukakan bahwa penyesuaian pilihan pekerjaan yang dianggap pokok adalah memilih bidang yang cocok dengan bakat, minat, dan faktor psikologis lainnya. Hal ini juga didukung oleh teori Person Environment Holland yang menyatakan bahwa memilih pekerjaan disesuaikan dengan minat, kemampuan, kebutuhan, dan nilai terkait dengan kesuksesan, kepuasan, dan stabilitas karir (Hughes \& Scott, 2013). Sekolah menjadi wadah yang membantu siswa dengan menyediakan kurikulum yang menjembatani antara kebutuhan pengembangan karir siswa dengan peranan pekerjaan di masa mendatang. Program semacam ini menurut Palladino Schultheiss, (2005) sangat penting untuk mempromosikan pembelajaran seumur hidup, lingkungan pendidikan yang produktif, dan masa depan transisi yang sukses dari sekolah ke kehidupan (Palladino Schultheiss, 2005). Rohany juga mengungkapkan bahwa persiapan karir sebaiknya dilakukan sedini mungkin saat anak-anak masih bersekolah (Talib et al., 2015).

Masa remaja adalah periode waktu yang penting dalam membentuk nilai, minat, dan kemampuan serta mengembangkan ideide informasi tentang pekerjaan masa depannya (Bartlett \& Domene, 2015). Tahap persiapan pindah ke dunia karir dari sekolah dan pilihan karir yang masuk akal dan menjadi periode perkembangan yang paling penting (Yun \& Min, 2015) karena memasuki masa transisi dari sekolah ke tempat kerja yang membutuhkan bimbingan (Hansen, 2015). Pekerjaan yang bagus membutuhkan pendidikan perencanaan karir dan keahlian yang bagus agar kelak siswa tidak mengalami kebingungan tentang arah karirnya (Musrifah, 2015). Perencanaan karir sebaiknya disiapkan secara matang agar dapat mendorong keinginan terus 
belajar dan mengembangkan berbagai potensi yang dimiliki. Masa SMP termasuk dalam tahap eksplorasi karir. Keterampilan, pemahaman tentang kompetensi, klasifikasi industri dan pekerjaan, hubungan antara masyarakat masa kini dan pekerjaan, pendidikan persiapan karir, membangun rencana karir masa depan yang potensial, pendaftaran dan kesiapan karir, makna dan kebutuhan terhadap pekerjaan serta kondisi pilihan dalam pemilihan pekerjaan, harus dipahami dan dieksplorasi (Yun \& Min, 2015). Remaja seharusnya mengeksplorasi pilihan karir masa depan dan menerapkan rencana karir berdasarkan minat, bakat, dan nilai mereka (Choi et al., 2015).

Mark Savickas dan para kolaboratornya mengklasifikasikan tiga periode penting teori dan intervensi karir. Yang pertama adalah vocational guidance, yang ditandai dengan meningkatkan pengetahuan diri, meningkatkan informasi pekerjaan, dan mencocokkan diri dengan pekerjaan. Yang kedua adalah career education, yang ditandai dengan menilai status perkembangan individu, berorientasi pada tugas perkembangan yang akan segera terjadi, dan mengembangkan sikap mengatasi keyakinan, dan kompetensi. Yang ketiga adalah career construction dan life design, yang dicirikan dengan membangun cerita karir, merekonstruksi plot dan tema, dan membuat potret kehidupan yang konsisten dengan paradigma desain kehidupan-karir (Fan \& Leong, 2016). Terdapat beragam bentuk intervensi berupa konseling kelompok yang bertujuan meningkatkan kematangan karir seperti life design counseling group (Cardoso et al., 2017); career planning decision-making based on cognitive science (Chen \& Zhou, 2018); rational-emotive behavior therapy (Ogbuanya et al., 2017); trait-factor theory based career counseling sessions (Atli, 2016); dan career counseling with juvenile offenders (Allen \& Bradley, 2015). Selain berupa konseling, terdapat juga bentuk intervensi yang lain berupa program khusus seperti career development courses (Hansen et al., 2017), guiding circles and hope-filled engagement (Hughes \& Scott, 2013), career exploration program (Cheung \& Jin, 2016; Ham \& Lim, 2017).

Di Indonesia topik perencanaan karir sebenarnya termasuk dalam mata pelajaran bimbingan dan konseling. Berdasarkan Permendiknas No. 22 Tahun 2006 tentang standar isi untuk satuan pendidikan dasar dan menengah menyebutkan bahwa pengembangan dan ekspresi diri peserta didik dilakukan sesuai kemampuan, bakat dan minat, diberikan melalui layanan konseling di sekolah. Akan tetapi fenomena yang terjadi di lapangan, meski sudah dilakukan melalui penyampaian materi di kelas, namun hasilnya kurang berdampak maksimal pada murid. Penelitian Erniwati (2017) menemukan bahwa siswa SMP Muhammadiyah 5 Surakarta belum memiliki gambaran tentang sekolah lanjutan berikutnya yang akan dituju. Siswa mengalami keraguan dan kebingungan untuk memilih sekolah lanjutan atas, mengalami perbedaan pendapat dengan orangtua terkait jurusan, dan siswa tidak tahu apakah jurusan yang dipilih sesuai dengan potensi yang dimiliki. Salah satu penyebabnya adalah kelemahan konselor dalam penguasaan materi mengenai karir (Musfirah, 2015) dan lebih banyak alokasi untuk materi lain terkait etika yang dianggap lebih dibutuhkan siswa dibanding karir (Erniwati, 2017).

Selain itu juga bisa disebabkan karena waktu layanan yang diberikan oleh guru bimbingan dan konseling yang sangat terbatas (Lutiyem, 2016; Nafisah et al., 2015) dan cara penyampaian yang cenderung monoton juga memengaruhi respon pasif murid dalam menerima informasi yang masuk (Lutiyem, 2016). Intervensi berupa psikoedukasi dibutuhkan untuk meningkatkan kemampuan 
pengambilan keputusan. Psikoedukasi penjurusan yang dilakukan oleh Erniwati pada 17 murid SMP Muhammadiyah Surakarta yang berisi lima materi yaitu, analisis diri, perkaya wawasan jenis-jenis jurusan di SMK maupun SMA, keyakinan diri untuk mampu bertahan dalam usaha menghadapi suatu masalah terkait masalah penjurusan, penentuan tujuan dan evaluasi mampu meningkatkan kemampuan pengambilan keputusan karir siswa (Erniwati, 2017).

Hasil yang sama juga ditunjukkan hasil penelitian lainnya bahwa modul dengan topik terkait, mampu membantu para siswa kelas IX sekolah menengah pertama dalam memilih karir (Ali \& Wiyono, 2018). Namun, psikoedukasi yang diberikan oleh kedua penelitian tersebut masih terbatas pada edukasi dalam tataran kognitif dan belum menyentuh pada tataran keterampilan berupa kemandirian dalam merencanakan karir. Keterlibatan orangtua masih dibutuhkan agar psikoedukasi yang diberikan efektif.

Penelitian mencoba meningkatkan kematangan karir siswa melalui pelatihan perencanaan karir dengan menggunakan pendekatan teori Cognitive Information Processing (CIP) yang terdiri dari lima tahapan pengambilan keputusan karir, yaitu Communicating, Analysing, Synthesis, Valuing, Excecution (CASVE) yang teruji mampu meningkatkan pengetahuan siswa pada tingkat pendidikan MA mengenai proses perencanaan karir dan juga keyakinan siswa mengenai karir yang dipilihnya (Akmal et al., 2016).

Beberapa alasan digunakannya metode pelatihan ini adalah selain mampu menyentuh tataran kemandirian siswa dalam merencanakan karir, pelatihan ini disusun dalam serangkaian kegiatan berkelompok yang simpel, santai dan menyenangkan, sehingga para murid tidak merasa bosan, serta sangat sesuai dengan usia siswa. Bentuk kegiatan yang dilakukan juga tidak hanya berupa ceramah satu arah dari pemateri melainkan juga diskusi antar peserta dan penayangan film pendek yang memberikan kesan mendalam sehingga para subjek dapat mengambil nilai positif dari perjalanan tokoh dalam film tersebut. Kegiatan juga dilengkapi modul berupa buku aktivitas yang dicetak sehingga dapat menyajikan informasi dalam jumlah banyak dan dapat dipelajari dimana saja dan kapan saja karena mudah dibawa. Selain itu, buku aktivitas juga didesain sedemikian rupa juga akan menambah semangat para siswa untuk mempelajari isinya (Nursalim, 2013).

Berdasarkan pemaparan tersebut, hipotesis penelitian ini adalah pelatihan perencanaan karir dapat meningkatkan kematangan karir siswa SMP. Tujuan penelitian adalah untuk meningkatkan kematangan karir melalui pelatihan perencanaan karir pada siswa SMP.

\section{METODE PENELITIAN}

\section{Desain Penelitian}

Desain ekperimen yang digunakan yaitu kuasi eksperimen dengan desain one group prates-paskates group, yaitu menggunakan satu kelompok subjek dilakukan pengukuran sebelum dan sesudah pemberian perlakuan. Perbedaan yang dihasilkan dari pengukuran tersebut yang dianggap sebagai efek perlakuan (Latipun, 2015). 


$$
\text { Pengukuran }\left(\mathrm{O}_{1}\right) \rightarrow \text { Intervensi } \rightarrow \text { Pengukuran }\left(\mathrm{O}_{2}\right)
$$

Gambar 1. Desain one group pretest-post test group

Keterangan:
$\mathbf{0}_{1}=$ Tes awal (prates) sebelum pelatihan diberikan.
$\mathbf{X}=$ Perlakuan atau pelatihan terhadap kelompok subjek
$\mathbf{0}_{2}=$ Tes akhir (post-test) setelah diberikan pelatihan

\section{Subjek Penelitian}

Penelitian ini melibatkan siswa kelas IX Sekolah Menengah Pertama (SMP) Negeri di Kota Malang dengan cara teknik purposive sampling, yaitu mengambil sampel tidak dengan random melainkan dengan pertimbangan kriteria tertentu (Sugiyono, 2009). Subjek penelitian berusia antara 14 16 tahun, dan memiliki skor kematangan karir rendah. Screening dilakukan dengan memberikan skala kematangan karir kepada 66 siswa, dan didapatkan 10 siswa yang berada pada kategori skor kematangan karir rendah, dengan kategori kematangan karir sebagai berikut $=(1)$ rendah : $\mathrm{x}<57$; (2) sedang : $57 \leq x \leq 72$; (3) tinggi : $x>72$. Adapun lebih detail data demografi subjek penelitian sebagaimana tabel 1 berikut ini:

Tabel 1. Karakteristik subjek

\begin{tabular}{ccccc}
\hline Subjek & Jenis Kelamin & Usia & skor & Keterangan \\
\hline 1 & L & 15 & 35 & rendah \\
2 & P & 16 & 55 & rendah \\
3 & L & 16 & 56 & rendah \\
4 & L & 16 & 56 & rendah \\
5 & L & 15 & 48 & rendah \\
6 & L & 16 & 55 & rendah \\
7 & L & 15 & 52 & rendah \\
8 & L & 15 & 48 & rendah \\
9 & L & 16 & 54 & rendah \\
10 & L & 16 & 53 & rendah \\
\hline
\end{tabular}

Keterangan : $L=$ Laki-laki; $P=$ Perempuan

\section{Metode Pengumpulan Data}

Pengumpulan data menggunakan alat ukur yang diadaptasi dari skala kematangan karir (Career Development Inventory /CDI) yang pernah dipakai Rahma \& Rahayu (2018) berdasarkan teori Super's structural model of career maturity dari Super, Thompson, Lindeman, Jordaan, \& Myers dengan lima aspek kematangan karir, yaitu (1) Career planning, timbulnya keinginan merencanakan masa depan, mencari informasi yang dibutuhkan melalui kegiatan di luar jam sekolah, (2) Career exploration, menggunakan berbagai sumber yang ada untuk mengetahui informasi mengenai minat dan pilihan studi lanjutannya selepas lulus SMP, (3) Decision making, mampu menggunakan informasi dan wawasan untuk memilih studi lanjutan selepas SMP yang sesuai dengan minat dan kemampuan, (4) World of work information, mengetahui karakteristik pilihan studi lanjutannya selepas lulus SMP, (5) Knowledge of the preffered occupational group, mengetahui materi, kelompok mata 
pelajaran, dan syarat-syarat apa yang dibutuhkan. Instrumen kematangan karir ini terdiri dari 21 item dengan empat alternatif jawaban. Pada item favorable, diberi skor 4 untuk SS (Sangat Setuju), 3 untuk S (Setuju), 2 untuk TS (Tidak Setuju), dan 1 untuk STS (Sangat Tidak Setuju) sedangkan pada item unfavorable, diberi skor 1 untuk SS (Sangat Setuju), 2 untuk S (Setuju), 3 untuk TS (Tidak Setuju), dan 4 untuk STS (Sangat Tidak Setuju). Instrumen ini reliabel dengan nilai Cronbach's alpha sebesar 0.88. Sedangkan berdasarkan hasil uji coba skala memiliki indeks validitas $0.263-0.709$ dan reliabilitas sebesar 0.889 . Maka skala yang digunakan dalam penelitian ini valid dan memiliki reliabilitas yang tinggi. Instrumen ini juga dipilih karena memiliki dasar teori yang digunakan peneliti, yaitu mengacu pada lima aspek kematangan karir dari teori perkembangan karir dari Super. Selain itu instrumen menggunakan bahasa yang sesuai dengan subjek dalam penelitian ini yaitu remaja sekolah menengah pertama.

\section{Prosedur Intervensi}

Pelatihan dilaksanakan dalam rentang tiga minggu, sebanyak tiga kali pertemuan atau setara dengan enam jam pelajaran ( 240 menit). Peneliti sebagai observer dibantu oleh 1 orang trainer melakukan serangkaian kegiatan pelatihan. Berikut prosedur intervensi yang dilakukan sebagaimana pada tabel 2 .

Tabel 2. Prosedur intervensi

Hari Pertama

\begin{tabular}{|c|c|c|}
\hline Sesi & Waktu & Kegiatan \\
\hline 1 & $15^{\prime}$ & $\begin{array}{l}\text { Pembukaan dan menjalin kesepakatan agar kegiatan dapat berjalan dengan lancar dan } \\
\text { kondusif. }\end{array}$ \\
\hline \multirow[t]{2}{*}{2} & 30 & "Dimana Aku" \\
\hline & & $\begin{array}{l}\text { Tujuan agar peserta mampu memahami tugasnya sebagai remaja dalam } \\
\text { pengembangan karir dan memahami faktor apa saja yang dibutuhkan untuk } \\
\text { merencanakan karir }\end{array}$ \\
\hline \multirow[t]{2}{*}{3} & $45^{\prime}$ & "Rumus Karir" \\
\hline & & $\begin{array}{l}\text { Tujuan agar peserta makin memahami konsep karir serta hubungannya dengan minat, } \\
\text { bakat dan cita-cita }\end{array}$ \\
\hline \multirow[t]{2}{*}{4} & $10^{\prime}$ & Closing dan feedback \\
\hline & & $\begin{array}{l}\text { Tujuan untuk menyimpulkan seluruh kegiatan yang telah dilakukan dan melihat } \\
\text { seberapa faham peserta dengan materi yang diberikan }\end{array}$ \\
\hline \multicolumn{3}{|c|}{ Hari kedua } \\
\hline Sesi & Waktu & Kegiatan \\
\hline 1 & $10^{\prime}$ & $\begin{array}{l}\text { Pembukaan: bertujuan agar peserta makin mengenal satu dengan yang lain, } \\
\text { penyampaian tujuan kegiatan dan mengingatkan kembali kesepakatan dalam } \\
\text { pelatihan }\end{array}$ \\
\hline \multirow[t]{2}{*}{2} & $40^{\prime}$ & Evaluasi Diri \\
\hline & & $\begin{array}{l}\text { Tujuan: peserta mampu memahami bakat minat, kelebihan dan kekurangan dalam } \\
\text { menggapai cita-cita atau pilihan karir yang diinginkan untuk lebih memahami apa } \\
\text { yang dibutuhkan untuk mempersiapkan masa depan karirnya }\end{array}$ \\
\hline \multirow[t]{2}{*}{3} & $40^{\prime}$ & Aku Pasti Bisa \\
\hline & & $\begin{array}{l}\text { Tujuan : mengajak peserta menganalisis berbagai kendala yang mungkin muncul } \\
\text { dalam menggapai cita-citanya dan bagaimana mengatasinya }\end{array}$ \\
\hline \multirow[t]{2}{*}{4} & $10^{\prime}$ & Closing dan feedback \\
\hline & & $\begin{array}{l}\text { Tujuan: menyimpulkan seluruh kegiatan yang telah dilakukan dan melihat seberapa } \\
\text { faham peserta dengan materi yang diberikan }\end{array}$ \\
\hline
\end{tabular}




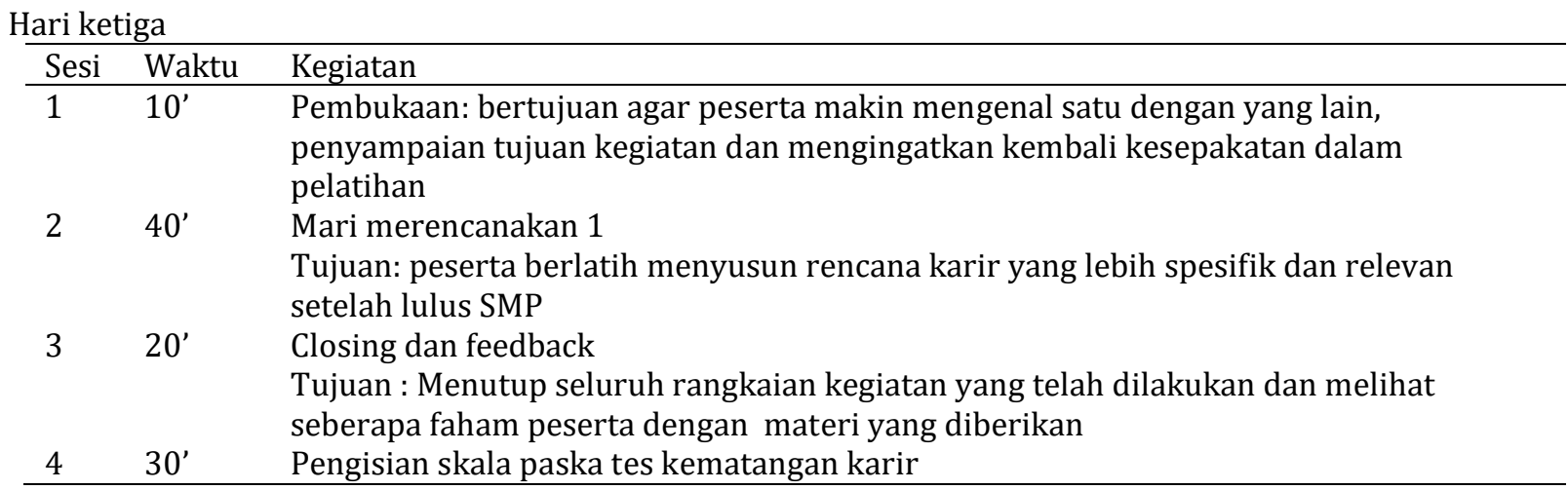

Analisis data menggunakan uji Wilcoxon dengan bantuan Statistical Package for Social Sciences (SPSS). Diawali dengan uji normalitas data, kemudian menganalisis data skor prates dan paska tes untuk mengetahui efek dari pelatihan.

\section{HASIL PENELITIAN}

Hasil penelitian menunjukkan adanya perubahan skor kematangan karir dari 10 subjek penelitian. Perbandingan skor prates dan paskates sebagaimana pada tabel 3 :

Tabel 3. Perbandingan skor prates dan paska tes

\begin{tabular}{cccc}
\hline Subjek & Skor Prates & Skor Paska Tes & Selisih \\
\hline 1 & 35 & 57 & 22 \\
2 & 55 & 61 & 6 \\
3 & 56 & 59 & 3 \\
4 & 56 & 61 & 5 \\
5 & 48 & 57 & 9 \\
6 & 55 & 62 & 7 \\
7 & 52 & 59 & 7 \\
8 & 48 & 57 & 9 \\
9 & 54 & 58 & 4 \\
10 & 53 & 61 & 8 \\
\hline Total & 512 & 592 & 80 \\
\hline Rata-rata & 51,2 & 59,2 & 8 \\
\hline
\end{tabular}

Sebagaimana tabel 3 skor prates dan paska tes seluruh subjek meningkat dengan rata-rata skor selisih sebesar 8. Adapun hasil analisis sebagaimana pada tabel 4 .

Tabel 4. Hasil analisis data

\begin{tabular}{lllll}
\hline & N & Mean & Z & P \\
\hline Prates & 10 & 51,2 & $-2,807$ & 0,0025 \\
Paska Tes & 10 & 59,2 & & \\
\hline
\end{tabular}


Volume 12, Nomor 2, Desember 2020

Berdasarkan hasil analisis sebagaimana pada tabel 4 menunjukkan pelatihan perencanaan karir mampu meningkatkan kematangan karir pada remaja sekolah menengah pertama.

\section{PEMBAHASAN}

Hasil penelitian menunjukkan adanya kenaikan skor kematangan karir melalui pelatihan perencanaan karir. Hal ini dibuktikan dengan adanya perbedaan tingkat skor kematangan karir antara sebelum dan sesudah intervensi. Tingkat perubahan didasarkan hasil analisis uji beda yang menunjukkan terdapat perbedaan yang signifikan antara sebelum dan setelah diberi perlakuan. Hal ini didukung penelitian sebelumnya yang mengungkapkan bahwa intervensi berbentuk pelatihan mampu meningkatkan efikasi diri dalam pengambilan keputusan karir siswa SMP (Lohmay et al., 2017; Widyastika et al., 2015).

Pelatihan perencanaan karir yang dilakukan diawali dengan sesi "Dimana Aku" yang merupakan tahap communicating, bertujuan memunculkan kesadaran bahwa sudah saatnya untuk membuat pilihan karir sebagai seorang remaja. Pada sesi ini siswa diajak memahami konsep bakat dan minat sebagai landasan dalam membuat pilihan karir yang bijak. Siswa tidak mengalami kesulitan dalam memahami materi yang diberikan, akan tetapi mengalami kesulitan dalam menilai diri sendiri baik bakat atau minatnya. Siswa lebih banyak menjawab hal yang sama saat diminta menyebutkan minat, yaitu bermain game online dan bermain sosial media. Kondisi semacam ini disebabkan banyak faktor beban belajar yang terlalu banyak seringkali membuat siswa merasa jenuh hingga membuat mereka kehilangan waktu untuk dirinya sendiri, bermain, maupun mengembangkan hobi dan pilihan refreshing paling praktis
DOI :10.20885/intervensipsikologi.vol12.iss2.art5 yaitu handphone sebagai alat komunikasi yang paling sering digunakan (Setyawati, 2018). Padahal berdasarkan kurikulum 2013, lewat proses pendidikan di sekolah siswa diharapkan bisa mengembangkan kemampuan dan minatnya secara terarah dan optimal (Direktorat Jenderal Pendidikan Dasar, 2014).

Ketidakmampuan siswa dalam mengemukakan bakatnya juga disebabkan karena tidak terbiasa untuk memberikan penilaian atas potensi yang dimilikinya. Hal ini sesuai dengan pendapat Super yang menyatakan bahwa konsep diri memiliki keterkaitan dengan kematangan karir, karena konsep diri yang positif akan lebih mudah mengembangkan potensinya dalam rangka mendukung perencanaan karir yang bijak (Suryanti et al., 2011).

Pada sesi "Rumus Karir", yang bertujuan untuk memperluas wawasan karir dan menjelaskan konsep perencanaan karir yang baik. Beberapa siswa kesulitan saat diminta untuk menyebutkan cita-cita karirnya di masa mendatang sementara sebagian lainnya memilih cita-cita yang tidak sesuai dengan bakat dan minatnya. Siswa merasa bahwa cita-cita termasuk dalam masa depan yang tidak harus dipikirkan dengan serius di masa kini. Pola pikir terlalu santai seperti ini bisa menimbulkan kecenderungan untuk terjadinya salah pilihan di masa depan karena kurangnya persiapan. Untuk itulah pada sesi ini, menekankan adanya keterkaitan antara masa kini dan masa depan serta bagaimana pendidikan sekolah yang sedang dijalani untuk mempersiapkan karirnya (Zunker, 2006).

Pada sesi "Evaluasi", siswa dibimbing untuk membuat berbagai pilihan karir berdasarkan materi yang telah diberikan sebelumnya. Pada sesi ini siswa kesulitan dalam membuat pilihan. Kesulitan dalam hal ini menurut Gati, Krausz dan Osipow terdiri dari tiga aspek, yaitu (1) kurangnya 
kesiapan, enggan membuat keputusan karir; (2) kurangnya informasi; (3) informasi yang dimiliki tidak konsisten (Islamadina \& Yulianti, 2016). Lebih lanjut Osipow mengungkapkan bahwa kesulitan yang dirasakan dalam membuat keputusan yang berkaitan dengan karir dapat mencakup kepercayaan yang kurang tepat tentang pengambilan keputusan karir, kurangnya motivasi, atau keragu-raguan (Tressler, 2015).

Kesulitan membuat pilihan karir juga merujuk pada sesi sebelumnya dimana para subjek masih kurang memahami konsep karir, seperti bingung dengan bakat dan minatnya, info tentang prospek pilihan yang sedikit, kemampuan yang belum cukup untuk memilih (Izzawati \& Lisnawati, 2015). Salah satu metode yang dilakukan untuk mengatasi adalah dengan menjadikan lembar kerja "Evaluasi" sebagai homework, dan siswa diperbolehkan mencari jawaban dari berbagai sumber. Dengan adanya penugasan, siswa memiliki waktu lebih banyak melakukan ekplorasi tentang karir di luar dari jam pelatihan. Hal ini juga bertujuan untuk memunculkan inisiatif dan kemandirian subjek dalam memenuhi tugas karirnya sebagai remaja.

Eksplorasi aktif adalah pusat atau inti dari proses decision making pada remaja (Bardick et al., 2006). Melalui eksplorasi, siswa diharapkan mampu mengumpulkan berbagai wawasan yang dibutuhkan untuk merencanakan karir dari berbagai sumber informasi yang ada di sekitarnya. Penelitian terdahulu menyebutkan bahwa eksplorasi karir secara positif memengaruhi pengambilan keputusan karir (Cheung \& Jin, 2016; Tressler, 2015), karena informasi yang dikumpulkan melalui eksplorasi karir dapat memperkuat minat individu dan mengurangi ketidakpastian dari minimnya informasi (Park et al., 2016).

Melalui sesi, "Aku Pasti Bisa", siswa diajak menonton film pendek bersama tentang perjalanan karir pesepak bola yang mendapat tantangan dari keluarga dan bagaimana jalan yang ditempuh untuk menghadapinya. Pembelajaran melalui film dapat membantu siswa untuk memahami dan mengenali pesan tentang sikap dan nilai-nilai kemanusiaan yang disampaikan dalam film (Blasco et al., 2015). Setelah menganalisa pesan moral dari film secara bersama-sama, dilanjutkan pemberian materi singkat terkait kendala yang muncul dalam mewujudkan perencanaan karir dan beberapa macam cara penyelesaian. Selain itu tujuan lain dari tahap ini adalah untuk meningkatkan optimisme dalam menghadapi masa depan. Pada sesi ini, siswa memperlihatkan antusiasme dan mulai menunjukkan perubahan terkait persepsinya terhadap dukungan orangorang sekitar dalam perencanaan karir. Siswa menyadari bahwa kebimbangan yang mereka rasakan sebaiknya bisa dikomunikasikan pada orang tua, guru, maupun teman sebaya.

Pada sesi terakhir "Mari Merencanakan", siswa dibimbing membuat perencanaan karir jangka pendek, yaitu pemilihan studi lanjut setelah lulus SMP. Sesi ini diawali dengan penyampaian materi mengenai jenis pilihan studi lanjut yang dapat dipilih, karakteristik sistem pendidikannya, serta persyaratannya. Berdasarkan hasil pengamatan, sesi ini merupakan sesi paling tenang karena siswa terlihat fokus dan mendengarkan. Hal ini dikarenakan siswa menemukan bahwa informasi yang disampaikan merupakan informasi yang penting, karena tidak lama lagi akan menghadapi kelulusan dan studi lanjut. Perencanaan karir yang dilakukan pada tahap ini berbeda dengan di tahap "Evaluasi" karena pada tahap ini, pilihan semakin dipersempit dengan pertimbangan lain selain faktor internal (minat, bakat, dan cita-cita), seperti kendala dan dukungan lingkungan sekitar. Meski masih banyak yang kesulitan dalam membuat perencanaan jangka pendek, para siswa tidak lagi malu 
untuk bertanya jika ada hal yang kurang dimengerti. Siswa juga mulai berpikir kritis bahwa saat merasa bimbang atau bingung atas pilihan studi lanjutnya, mereka berusaha mencari solusi dan jawaban dari berbagai sumber di sekitarnya. Werner (2017) menguraikan bahwa serangkaian tahapan dalam CASVE cycle bertujuan untuk mengembangkan keterampilan berpikir kritis seputar pengambilan keputusan karir. Teori pemrosesan informasi memungkinkan individu untuk memproses apa yang perlu mereka ketahui dan melalui siklus CASVE, dapat menuntun individu untuk mengetahui apa yang dibutuhkan dan perlu dilakukan dalam karirnya. Selain itu bentuk kegiatan pada beberapa sesi merupakan diskusi kelompok, sehingga para subjek dapat saling belajar lewat pengalaman satu sama lain yang disebut sebagai vicarious learning (Izzawati \& Lisnawati, 2015).

Selain itu, juga disusun buku aktivitas "DREAM" untuk mendukung berlangsungnya kegiatan. Buku aktivitas terdiri dari seluruh materi tiap sesi yang disajikan dalam bentuk yang praktis dan desain yang menarik, sehingga siswa lebih semangat untuk mempelajari isinya dan dapat dimanfaatkan bahkan setelah pelatihan berakhir. Beberapa penelitian terdahulu menyebutkan bahwa modul/handout sebagai media pendukung mampu membantu meningkatkan pemahaman terkait konsep karir (Ali \& Wiyono, 2018; Atmaja, 2014; Musfirah, 2015; Talib et al., 2015).

\section{SIMPULAN DAN SARAN}

Penelitian ini membuktikan bahwa pelatihan perencanaan karir mampu meningkatkan kematangan karir remaja SMP. Melalui pemahaman diri sendiri dan tanggung jawab terhadap tugas perkembangannya sebagai remaja, mampu memunculkan inisiatif dan kemandirian dalam mencari informasi yang dibutuhkan terkait keputusan karir ke depannya. Disarankan kepada pihak sekolah agar menggunakan pelatihan perencanaan karir sebagai metode pembelajaran siswa dalam melakukan pemahaman diri dan pemilihan studi lanjutan sebagai bagian dari perencanaan karir remaja. Selain itu bagi subjek penelitian, diharapkan agar senantiasa menambah wawasan baru terkait pilihan karir yang selalu berkembang dan studi lanjut sesuai dengan situasi dan kondisi.

\section{DAFTAR PUST AKA}

Afifah, R. (2013, October 25). Guru BK dilatih agar siswa tidak salah peminatan. Harian Kompas.

Akmal, S. Z., Arlinkasari, F., \& Brebahama, A. (2016). Intervensi untuk meningkatkan kematangan karier pada siswa MA CC. Prosiding Seminar Nasional Penelitian Dan PKM Kesehatan : Pemanfaatan Hasil Penelitian Dan Pengabdian Kepada Masyarakat Bagi Percepatan Pembangunan Berkelanjutan Di
Indonesia, 311-322.

Ali, A. R., \& Wiyono, B. D. (2018).

Pengembangan modul pemilihan karir untuk siswa kelas IX SMPN 3 Babat Lamongan. Jurnal BK Unesa, 8(2). https://jurnalmahasiswa.unesa.ac.id/i ndex.php/jurnal-bkunesa/article/view/23119

Allen, K. R., \& Bradley, L. (2015). Career counseling with juvenile offenders: Effects on self-efficacy and career maturity. Journal of Addictions and 
Offender Counseling, 36(1), 28-42. https://doi.org/10.1002/j.21611874.2015.00033.x

Aquila. (2012). Perbedaan pengalaman praktek kerja lapangan pada siswa SMA-SMK dan status keputusan karir terhadap kematangan karir [Tesis, Universitas Indonesia]. Universitas Indonesia, Depok.

Atli, A. (2016). The effects of trait-factor theory based career counseling sessions on the levels of career maturity and indecision of high school students. Universal Journal of Educational Research, 4(8), 18371847.

https://doi.org/10.13189/ujer.2016.0 40813

Atmaja, T. T. (2014). Upaya meningkatkan perencanaan karir siswa melalui bimbingan karir dengan penggunaan media modul. PSIKOPEDAGOGIA Jurnal Bimbingan Dan Konseling, 3(2), 58-68. https://doi.org/10.12928/psikopedag ogia.v3i2.4466

Bardick, A. D., Bernes, K. B., Magnusson, K. C., \& Witko, K. D. (2006). Junior high school students' career plans for the future. Journal of Career Development, 32(3), 250-271.

https://doi.org/10.1177/0894845305 279168

Bartlett, J., \& Domene, J. F. (2015). The vocational goals and career development of criminally involved youth. Journal of Career Development, 42(3), 229-243.

https://doi.org/10.1177/0894845314 547269

Blasco, P. G., Moreto, G., Blasco, M. G., Levites, M. ozenfeld, \& Janaudis, M. A. (2015). Education through movies: Improving teaching skills and fostering reflection among students and teachers. Journal for Learning through the Arts: A Research Journal on Arts Integration in Schools and Communities, 11(1).
https://doi.org/10.21977/D91112235 7

Brian R. Russ. (2016). Counselor preparation and adolescent youth: A study of clinical mental health counselors. Western Michigan University. https://scholarworks.wmich.edu/diss ertations/2463/

Cardoso, P., Janeiro, I. N., \& Duarte, M. E. (2017). Life design counseling group intervention with portuguese adolescents: A process and outcome study. Journal of Career Development, 45(2), 183-196.

https://doi.org/10.1177/0894845316 687668

Chen, S., \& Zhou, K. (2018). Career planning decision-making of college students based on cognitive science.

NeuroQuantology, 16(6), 487-493. https://doi.org/10.14704/nq.2018.16. 6.1662

Cheung, R., \& Jin, Q. (2016). Impact of a career exploration course on career decision making, adaptability, and relational support in Hong Kong. Journal of Career Assessment, 24(3), 481-496.

https://doi.org/10.1177/1069072715 599390

Choi, Y., Kim, J., \& Kim, S. (2015). Career development and school success in adolescents: The role of career interventions. Career Development Quarterly, 63(2), 171-186. https://doi.org/10.1002/cdq.12012

Dhayanandhan, B., Bohr, Y., \& Connolly, J. (2015). Developmental task attainment and child abuse potential in at-risk adolescent mothers. Journal of Child and Family Studies, 24(7), 19871998. https://doi.org/10.1007/s10826-0149998-0

Direktorat Jenderal Pendidikan Dasar, Direktorat Pembinaan Sekolah Menengah Pertama (Kementrian 
Pendidikan dan Kebudayaan) (2014). Panduan bimbingan dan konseling sekolah menengah pertama. Direktorat Pembinaan Sekolah Menengah Pertama

Erniwati. (2017). Program psikoedukasi penjurusan untuk meningkatkan kemampuan pengambilan keputusan dalam memilih sekolah lanjutan atas [Tesis, Universitas Muhammadiyah Surakarta]. Universitas Muhammadiyah Surakarta.

Fajriyah, R. (2015). Hubungan antara dukungan sosial orangtua dengan kematangan karir siswa SMA Muhammadiyah 1 Pekanbaru. Skripsi, Fakultas Psikologi Universitas Islam Negeri Sultan Syarif Kasim Riau, Pekanbaru.

Fan, W., \& Leong, F. T. L. (2016). Introduction to the special issue: Career development and intervention in chinese contexts. The Career Development Quarterly, 64(3), 192202. https://doi.org/10.1002/cdq.12054

Ham, K. A., \& Lim, H. W. (2017). Career maturity and quality of life in korean adolescents: A cross-lagged panel design. Career Development Quarterly, 65(3), 250-263.

https://doi.org/10.1002/cdq.12096

Hansen, J. M. (2015). A career course

follow-up: Does a student development elective make a difference?. Dissertation, Department of Counseling Psychology and Special Education Brigham Young University.

Hansen, J. M., Jackson, A. P., \& Pedersen, T. R. (2017). Career development courses and educational outcomes: Do career courses make a difference?. Journal of Career Development, 44(3), 209-223. https://doi.org/10.1177/0894845316 644984

Hughes, C., \& Scott, R. (2013). A career intervention for humanitarian entrant students: An example. Australian Journal of Career Development, 22(3), 130-138.

https://doi.org/10.1177/1038416213 502170

Islamadina, E. F., \& Yulianti, A. (2016). Persepsi terhadap dukungan orangtua dan kesulitan pengambilan keputusan karir pada remaja. Jurnal Psikologi, 12(1999), 33-38.

Izzawati, N., \& Lisnawati, L. (2015). Efektivitas pelatihan perencanaan karir terhadap peningkatan efikasi diri dalam pengambilan keputusan karir. Jurnal Psikologi Tabularasa, 10(1), 7088.

http://jurnal.unmer.ac.id/index.php/j pt/article/view/244

Latipun. (2015). Psikologi eksperimen (3rd ed.). UMM Press.

Lohmay, F., Triyono, T., \& Ramli, M. (2017). Keefektifan panduan pelatihan berbasis appreciative inquiry terhadap peningkatan kematangan karier siswa SMP. Jurnal Pendidikan: Teori, Penelitian \& Pengembangan, 2(1), 6572.

https://doi.org/http://dx.doi.org/10.1 7977/jp.v2i1.8440

Lutiyem. (2016). Peningkatan kematangan karier siswa melalui layanan konseling kelompok. Jurnal Penelitian Tindakan Bimbingan \& Konseling, 2(2). https://irpp.com/index.php/jptbk/article/vie $\mathrm{w} / 573$

Marliyah, L., Dewi, F. I. R., \& Suyasa, P. T. Y. S. (2004). Persepsi terhadap dukungan orangtua dan pembuatan keputusan karir remaja. Jurnal Provitae, 1(1), 5982. http://repository.untar.ac.id/1797/

Musfirah. (2015). Pengembangan modul perencanaan karier untuk siswa SMP. Jurnal Psikologi Pendidikan \& Konseling, 1(1), 39-49.

Nafisah, N. W., Padmomartono, S., \& 
Windrawanto, Y. (2015).

Meningkatkan kematangan karir remaja melalui teknik problem solving berbantuan media mind map. Jurnal Ilmiah Pendidikan, Sejarah, Dan Sosial Budaya Widya Sari, 17.

Nursalim, M. (2013). Pengembangan media bimbingan dan konseling (Yuan Acitra ed.). Akademia Permata.

Ogbuanya, T. C., Eseadi, C., Orji, C. T., Anyanwu, J. I., Ede, M. O., \& Bakare, J. (2017). Effect of rational emotive behavior therapy on negative career thoughts of students in technical colleges in Nigeria. Psychological Reports, 121(2), 356-374. https://doi.org/10.1177/0033294117 724449

Palladino Schultheiss, D. E. (2005). Elementary career intervention programs: Social action initiatives. Journal of Career Development, 31(3), 185-194. https://doi.org/10.1177/0894845305 03100303

Park, K., Woo, S., Park, K., Kyea, J., \& Yang, E. (2016). The mediation effects of career exploration on the relationship between trait anxiety and career indecision. Journal of Career Development, 44(5), 440-452. https://doi.org/10.1177/0894845316 662346

Purnamasari, D., Setyorini, \& Padmomartono, S. (2015). Tingkat kematangan karir siswa kelas VIII SMP Islam Sudirman Ambarawa. Widya Sari : Jurnal Pendidikan, Sejarah Dan Sosial Budaya, 17(2), 1-7. http://repository.uksw.edu/handle/1 23456789/6304

Rahma, U., \& Rahayu, E. W. (2018). The role of family social support on career maturity of the student junior high school student. Jurnal Ilmu Keluarga Dan Konsumen, 11(3), 194-205.

Santrock, J. W. (2011). Perkembangan masa hidup 13th edition (N. I. Sallama ed.). Penerbit Erlangga.

Setyawati, E. (2018). Hari pendidikan Indonesia belum memanusiakan manusia. Siedoo-Mengupas Pendidikan Dari Pelosok Negeri.

siedoo\%0AMengupas Pendidikan dari Pelosok Negeri

Sugiyono. (2009). Statistika untuk penelitian. CV. Alfabeta.

Sumiwi, C. M. A. . (2016). Hubungan minat terhadap pekerjaan dengan kepuasan kerja pada karyawan PT. Plambo Pemalang. Universitas Katolik Soegijapranata Semarang.

Suryanti, R., Yusuf, M., \& Priyatama, A. N. (2011). Hubungan antara locus of control internal dan konsep diri dengan kematangan karir pada siswa kelas XI SMK Negeri 2 Surakarta. Jurnal Wacana Psikologi, 3(1). https://doi.org/https://doi.org/10.13 057/wacana.v3i1.46

Talib, J. A., Salleh, A., Amat, S., Ghavifekr, S., \& Ariff, A. M. (2015). Effect of career education module on career development of community college students. International Journal for Educational and Vocational Guidance, 15(1), 37-55.

https://doi.org/10.1007/s10775-0149279-x

Telvisia, I., \& Suyasa, P. T. Y. S. (2008). Kesesuaian minat terhadap pekerjaan : Pegawai produktif (Studi pada agen asuransi jiwa di Jakarta ). Phronesis Jurnal Ilmiah Psikologi Industri Dan Organisasi, 10(1), 76-95.

Tressler, L. E. (2015). Increasing career exploratory behavior through message framing. Lousiana Tech University.

Werner, B. J. (2017). Assessing career decision-making status: The CASVE cycle questionnaire. Thesis, Department of Psychology University of Southern Mississippi. 
Widyastika, Y., Nugraha, S. P., \& Gusniarti, U. (2015). Pelatihan perencanaan karir untuk meningkatkan efikasi diri dalam pengambilan keputusan karir pada siswa kelas IX Madrasah Tsanawiyah " $X$ " Yogyakarta [Tesis, Universitas Islam Indonesia]. Fakultas Psikologi dan Ilmu Sosial Budaya Universitas Islam Indonesia.

Yun, S., \& Min, S. (2015). Analysis on occupational preference, career, aspiration and career attitude maturity of middle \& high school students.
Indian Journal of Science and Technology, 8(S7), 664-673. https://doi.org/10.17485/ijst/2015/v 8iS7/70469

Zunker, V. G. (2006). Career counselling a holistic approach (7th Editio). Thomson Brooks/Cole. https://doi.org/10.1017/CB09781107 415324.004 
Maulidia Ghassani, Ni'matuzahroh \& Zainul Anwar 